\title{
The Impact of Deviant Strategy on Corporate Innovation Performance: The Moderating Role of Equity Incentives and Market Competition
}

\author{
Chong Chen ${ }^{1, *}$ \\ ${ }^{1}$ School of Economics and Management, Beijing Jiaotong University, Beijing, Beijing 100044, China \\ ${ }^{*}$ Corresponding author. Email: chenchong37@163.com
}

\begin{abstract}
Related research has pointed out that the choice of corporate strategy can affect corporate performance, but the relationship between deviant strategy and corporate innovation performance has not been revealed. This article uses the 2007-2017 Chinese A-share listed companies as samples. The study found that corporate innovation performance is affected by deviant strategy, and there is a positive correlation between them; equity incentives will strengthen the relationship between deviant strategy and corporate innovation performance; however, market competition will weaken the relationship between deviant strategy and the innovation performance of enterprises. This research has certain theoretical significance and provides relevant suggestions for management practice.
\end{abstract}

Keywords: Deviant strategy, corporate innovation performance, equity incentive, market competition

\section{INTRODUCTION}

The strategy of the enterprise is very important to the development of the enterprise, which determines the development direction and progress of the enterprise for a period of time. Some enterprises in the development and operation process will be based on the industry's conventional strategy, in order to avoid risks and move forward steadily; while some enterprises find another way to implement the differentiation strategy, although facing higher risks, but can bring higher performance and benefits. The differentiation strategy deviating from the industry convention can stimulate the innovation potential of enterprises and improve the innovation performance of enterprises [1].

In the past, the research on enterprise strategic differences rarely involves the impact on the innovation performance of the enterprise itself. This research creatively considers the shortcomings of the relevant research. Combined with the analysis of the internal factors of equity incentive and the external conditions of market competition, this paper tries to explore how the enterprise strategic difference has an impact on enterprise innovation performance, and further clarify under what conditions this impact will be enhanced or weakened.

\section{THEORETICAL ANALYSIS AND RESEARCH HYPOTHESIS}

\subsection{Deviant Strategy and Corporate Innovation Performance}

According to the view of strategic integration, because enterprises in the same industry are facing similar market conditions and regulatory environment, and can learn from each other, there will be a trend of industry convergence in the process of industry development, which is reflected in the strategy as the industry's conventional strategy [1]. Deviant strategy refers to the deviation degree of the strategy selected by the enterprise compared with the conventional strategy of the industry [4].

It has been proved that the enterprises adopting the industry conventional strategy are faced with less business risk and stable development, but at the same time, their performance is moderate, and they can only obtain the average performance of the industry [4-6]. Compared with the industry's conventional strategy, enterprises with high deviant strategy face higher business risks [7]. On the one hand, because the unique strategic model can not be accepted by stakeholders, the enterprise may lead to business failure and achieve extremely poor performance. Such extreme performance 
makes the fluctuation of net profit increase and the persistence decrease, and the value relevance of profit weaken [4]. However, on the other hand, the differentiation strategy deviating from the industry convention can stimulate the innovation potential of enterprises, improve the innovation performance of enterprises [4], and obtain excellent business performance.

Enterprises with high deviant strategy adopt differentiated strategy, which is different from enterprises with conventional industry strategy. They are often faced with higher risks, and in return, they tend to have better innovation performance. Therefore, this study puts forward the hypothesis 1: deviant strategy has a positive impact on corporate innovation performance, the higher deviant strategy, the better the innovation performance will be.

\subsection{The Moderating Effect of Equity Incentive}

Some scholars found that executive monetary compensation can promote the company's R \& D Investment [8]. According to the principal-agent theory, the ownership and control of an enterprise are separated, the managers and shareholders are not a community of interests. In many cases, the company may even suffer losses due to inconsistent goals. Enterprises that deviate from the conventional industry strategy are faced with uncertainty and high risk [9], and equity incentive plan can give long-term satisfactory returns to incentive objects [10]. Therefore, equity incentive can reduce the short-sighted behavior of the company's management and improve its tolerance of failure [10]. Therefore, the management of the enterprise implementing equity incentive will support the strategy with high deviant strategy strongly.

Therefore, this study believes that when enterprises adopt high deviant strategy, the interests of executives and shareholders will be more consistent, which ensures the improvement of enterprise innovation performance. Based on the above analysis, this paper puts forward hypothesis 2: when other conditions remain unchanged, equity incentive will enhance the impact of deviant strategy on corporate innovation performance.

\subsection{The Moderating Effect of Market Competition}

According to the view of environmental uncertainty, the decision-making behavior of enterprise managers depends on the information provided by the environment, so managers will take environmental factors into consideration when making enterprise strategy, and adjust the enterprise strategy appropriately according to environmental changes [4].
The limited rational decision-making mode holds that the "rationality" proposed by the rational decisionmaking mode does not exist at all in reality. Therefore, when making a choice, they will use the "satisfactory choice" to replace the "optimal choice". Under the condition of environmental uncertainty, the implementation of industry conventional strategy is the most "satisfactory choice" for both enterprises and managers. The differentiation strategy that deviates from the industry's routine has relatively large business risk and information risk, and the impact of environmental uncertainty makes these risks further amplified [7]. When the enterprise is in a highly competitive and highly uncertain industry, the operators will act as rational economic man. Considering the maximization of their own interests, they are more inclined to avoid risks and follow the rules. Therefore, due to the higher external market competition, enterprise managers will be more conservative and rational, so they will choose the strategy that does not deviate from the industry convention, and the enterprise innovation performance will be worse.

Therefore, hypotheses 3 are put forward: when other conditions remain unchanged, market competition will weaken the impact of deviant strategy on enterprise innovation performance.

\section{RESEARCH DESIGN}

\subsection{Sample Selection and Data Sources}

In order to ensure the reliability of the research results, this study selects A-share listed companies in China from 2007 to 2017 as the samples. In the process of sample selection, we excluded companies with special treatment such as finance and insurance, st and other companies, as well as samples with missing data and abnormal observations, and finally obtained 13554 sample observations. All data were collected from CSMAR database. Spss26.0 software was used for data analysis. A total of 1108 data were collected.

\subsection{Definition of Variables}

\subsubsection{Dependent Variable}

Corporate innovation performance (CIP). This paper uses the sum of the number of invention patent applications and patent applications (up to the end of 2018) to measure the company's innovation performance [11], and selects $t+1$ period, taking the natural logarithm. 


\subsubsection{Independent Variable}

$$
\begin{aligned}
D S= & \left\{\left|\left(\frac{S C}{B I}-\partial_{1}\right) / \sigma_{1}\right|+\left|\left(\frac{N V I A}{B I}-\partial_{2}\right) / \sigma_{2}\right|+\left|\left(\frac{F A}{N S}-\partial_{3}\right) / \sigma_{3}\right|+\left|\left(\frac{G A}{B I}-\partial_{4}\right) / \sigma_{4}\right|+\right. \\
& \left.\left|\left(\frac{N F A}{O F A}-\partial_{5}\right) / \sigma_{5}\right|+\left|\left(\frac{S D+L D+B P}{T E}-\partial_{6}\right) / \sigma_{6}\right|\right\} / 6
\end{aligned}
$$

Deviant strategy (DS). Referring to Tang et al. (2011) model [4], the calculation model is as follows:

In the above formula, $\mathrm{SC}$ is sales expenses, $\mathrm{BI}$ is operating income, NVIA is net intangible assets, FA represents fixed assets, NS represents number of employees, GA represents management expenses, NFA and OFA represent net value and original value of fixed assets respectively, $\mathrm{SD}, \mathrm{LD}, \mathrm{BP}$ and Te refers to the book value of short-term loans, long-term loans, bonds payable and equity respectively, while alpha and $\sigma$ correspond to the average value and standard deviation of the industry respectively.

\subsubsection{Moderated Variables}

Market competition (MC). Measured by industry competitiveness. Select the profit rate of main business, inventory turnover rate and accounts receivable turnover rate, and take the reciprocal to turn them into positive indicators for principal component analysis to get the composite index CM. The larger the index is, the more fierce the product market competition is.

Equity incentive (EI). Equity incentive is a longterm stock based incentive for senior executives and employees in important positions. In this paper, equity incentive is measured by the extent of executive equity incentive plan granted.

\subsubsection{Control Variables}

Control variables include: nature of property rights (Nature), company size (Cs), Ratio of income as percentage of sales (Ros), asset-liability ratio (Lev), growth rate of total asserts (Goa), return on equity (Roe), employee size (Eint), duality (Dual), equity concentration (Ec), industry (Ind).

\subsection{Computational Models}

In order to test hypothesis 1, this study constructs the formula (1). Formulas (2) and (3) are the regression models that include market competition (MC) and equity incentive (EI) respectively. In order to test hypothesis 2 , this study constructs the interaction term between deviant strategy and market competition, see formula (4); similarly, the interaction term between deviant strategy and equity incentive is included in the model of formula (5) to test hypothesis 3. Among them, Control refers to all control variables.

$$
\begin{aligned}
& \mathrm{CIP}=\partial_{0}+\partial_{1} \mathrm{DS}+\partial_{2} \text { Control }+\delta_{1} \\
& \mathrm{CIP}=\beta_{0}+\beta_{1} \mathrm{MC}+\beta_{2} \text { Control }+\delta_{2} \\
& \mathrm{CIP}=\gamma_{0}+\gamma_{1} \mathrm{EI}+\gamma_{2} \text { Control }+\delta_{3} \\
& \mathrm{CIP}=\mu_{0}+\mu_{1} \mathrm{DS}+\mu_{2} \mathrm{MC}+\mu_{3} \mathrm{DS} * \mathrm{MC}+\mu_{4} \text { Control }+\delta_{4} \\
& \mathrm{CIP}=\varpi_{0}+\varpi_{1} \mathrm{DS}+\varpi_{2} \mathrm{EI}+\varpi_{3} \mathrm{DS} * \mathrm{EI}+\varpi_{4} \text { Control }+\delta_{5}
\end{aligned}
$$

\section{EMPIRICAL ANALYSIS}

\subsection{Main Effect Test}

Table 1. Multiple regression analysis

\begin{tabular}{cccc}
\hline Variable & Model 1 & Model 2 & Model 3 \\
\hline DS & $0.376^{* * *}(17.62)$ & & \\
MC & & $-0.002(-1.24)$ & \\
El & & & $0.025^{* *}(2.67)$ \\
Nature & $-0.004(-0.65)$ & $-0.001(-0.35)$ & $-0.003(-0.48)$ \\
Cs & $-0.025^{* * *}(-3.62)$ & $-0.050^{\star * *}(-$ & $-0.048^{* * *}(-3.72)$ \\
Ros & $-0.004(-0.51)$ & $-0.004(-0.48)$ & $-0.001(-0.55)$ \\
Lev & $0.068^{* * *}(3.32)$ & $0.122^{* *}(2.67)$ & $0.114^{* *}(2.59)$ \\
Goa & $-0.001(-0.86)$ & $-0.001(-0.68)$ & $-0.002(-0.74)$ \\
Roe & $0.001(1.35)$ & $0.001(1.21)$ & $0.001(1.01)$ \\
Eint & $-0.041^{* * *}(-5.98)$ & $-0.023^{* * *}(-$ & $-0.042^{* * *}(-5.27)$ \\
Dual & $0.008(0.92)$ & $0.010(0.83)$ & $0.005(0.41)$ \\
Ec & $0.184^{* * *}(4.65)$ & $0.116(1.24)$ & $0.125^{*}(2.04)$ \\
Industry $/$ yea & control & control & control \\
R-squared & 0.142 & 0.159 & 0.152 \\
F Statistic & 32.54 & 33.17 & 54.52 \\
\hline Note: $*$ P $<0.05, * * \mathrm{P}<0.01, * * * \mathrm{P}<0.001 ;$ the values in brackets are t-test values.
\end{tabular}

It can be seen from table 1 that model 1 shows that the regression coefficient of deviant strategy on corporate innovation performance is $0.376(\mathrm{t}=17.62, \mathrm{P}$ $<0.001)$, indicating that deviant strategy has a 
significant positive impact on corporate innovation performance. The results of model 1 verify the validity of hypothesis 1. Model 2 tests the impact of market competition (MC) on corporate innovation performance, and the regression coefficient is $-0.002(\mathrm{t}=-1.24, \mathrm{P}>$ $0.05)$, which shows that there is no significant correlation between market competition and corporate innovation performance. Model 3 tests the impact of equity incentive (EI) on corporate innovation performance, and the regression coefficient is $0.025(\mathrm{t}=$ $2.67, \mathrm{P}<0.001)$, indicating that equity incentive has a significant positive correlation with corporate innovation performance.

\subsection{Analysis of Moderated Effect}

Table 2 shows that model 5 adds the moderated variable (EI) and the interaction term (DS*EI) on the basis of model 1 in table 1 . From the results of model 5 , the regression coefficient of DS*EI is $0.028(\mathrm{t}=2.66, \mathrm{P}$ $<0.01$ ), which shows that equity incentive can strengthen the positive relationship between deviant strategy and innovation performance. Therefore, hypothesis 2 is supported by the data.

Model 4 is based on model 1 in table 1 , adding the moderator (MC) and the interaction (DS * MC). From the results of model 4 , the regression coefficient of DS*MC is $-0.038(\mathrm{t}=2.95, \mathrm{P}<0.01)$, which indicates that market competition can weaken the positive relationship between deviant strategy and innovation performance. Therefore, hypothesis 3 is supported.

Table 2. Moderated effect

\begin{tabular}{|c|c|c|}
\hline Variable & Model 4 & Model 5 \\
\hline DS & $0.328^{* * *}(7.25)$ & $0.286^{\star \star \star}(6.02)$ \\
\hline MC & $-0.004(-1.05)$ & \\
\hline El & & $0.002(0.28)$ \\
\hline $\mathrm{DS} * \mathrm{MC}$ & $-0.038^{\star *}(2.95)$ & \\
\hline DS*EI & & $0.028^{\star \star}(2.66)$ \\
\hline Nature & $-0.004(-0.68)$ & $-0.004(-0.70)$ \\
\hline Cs & $-0.035^{\star *}(-2.96)$ & $-0.041^{* * *}(-3.95)$ \\
\hline Ros & $-0.005(-1.21)$ & $-0.003(-0.62)$ \\
\hline Lev & $0.119^{\star *}(2.63)$ & $0.120^{* *}(2.78)$ \\
\hline Goa & $-0.005(-0.29)$ & $-0.003(-0.25)$ \\
\hline Roe & $0.001(0.95)$ & $0.001(0.87)$ \\
\hline Eint & $-0.044^{\star \star \star}(-5.85)$ & $-0.059^{\star * *}(-0.62)$ \\
\hline Dual & $0.004(0.86)$ & $0.009(1.01)$ \\
\hline Ec & $0.049(0.81)$ & $0.052(0.53)$ \\
\hline Industry/year & control & control \\
\hline R-squared & 0.182 & 0.201 \\
\hline F Statistic & 50.28 & 54.02 \\
\hline
\end{tabular}

\section{CONCLUSION}

There are some differences in the innovation performance of Chinese listed companies, among which deviant strategy is one of the factors, and there is a positive correlation between them, that is, the higher deviant strategy, the better the innovation performance. At the same time, the external market competition and internal equity incentive will have an impact on the relationship between deviant strategy and innovation performance. If enterprises are faced with incentive market competition, executives will prefer conservative attitude and strategy, and then the positive impact of deviant strategy on corporate innovation performance will be weakened. If the degree of equity incentive is high, managers will tend to safeguard the interests of shareholders. At this time, the executives of enterprises with high deviant strategy will play their personal ability to implement the strategy and bring higher innovation performance. That is to say, equity incentive will strengthen the impact of deviant strategy on corporate innovation performance.

Deviant strategy provides a new perspective for the research of enterprise innovation. This paper is an attempt. Which factors will affect the effect of deviant strategy on corporate innovation performance? These problems have not yet been solved. This paper calls for further research on related issues.

\section{REFERENCES}

[1] D. L. Deephouse, To be different, or to be the same? It's a question (and theory) of strategic balance, Strategic Management Journal. 20(2) (1999) 147166. DOI: https://doi.org/10.1002/(SICI)10970266(199902)20:2<147::AID-SMJ11>3.0.CO;2-Q

[2] M. A. Hitt, R. D. Ireland, Hoskisson R E. Strategic management: competitiveness \& globalization: concepts, West Publishing Company, 2011.

[3] J. W. Meyer, B. Rowan, Institutionalized Organizations: Formal Structure as Myth and Ceremony, American Journal of Sociology. 83(2) (1977) 340-363. DOI: https://doi.org/10.1086/226550

[4] J. Tang, M. Crossan, W. G. Rowe, Dominant CEO, Deviant Strategy, and Extreme Performance: The Moderating Role of a Powerful Board, Journal of Management Studies. 48(7) (2011) 1479-1503. DOI: https://doi.org/10.1111/j.14676486.2010.00985.x

[5] P. J. Dimaggio, W. W. T. Powell, The Iron Cage Revisited: Institutional Isomorphism and Collective Rationality in Organizational Fields, American Sociological Review. 48(2) (1983) $147-$ 160. DOI: https://doi.org/10.2307/2095101 
[6] C. Oliver, Strategic Responses To Institutional Processes, Academy of Management Review. 16(1) (1991) 145-179. DOI: https://doi.org/10.5465/AMR.1991.4279002

[7] M. A. Geletkanycz, D. C. Hambrick, The External Ties of Top Executives: Implications for Strategic Choice and Performance, Administrative Science Quarterly. 42(4) (1997) 654-681. DOI: https://doi.org/10.2307/2393653

[8] S. Cheng, R\&D Expenditures and CEO Compensation, Accounting Review. 20(1) (2004) 256-269. DOI: https://doi.org/10.1046/j.13652818.2001.00767.x

[9] B. Holmstrom, Agency costs and innovation, Journal of Economic Behavior \& Organization. 12(3) (1989) 305-327. DOI: https://doi.org/10.1016/0167-2681(89)90025-5

[10] G. Manso, Motivating Innovation, Journal of Finance. 66(5) (2011) 1823-1860. DOI: https://doi.org/10.1111/j.1540-6261.2011.01688.x

[11] R. Yuan, W. Wen, Managerial Foreign Experience and Corporate Innovation, Journal of Corporate Finance. (48) (2018) 752-770. DOI: https://doi.org/10.1016/j.jcorpfin.2017.12.015 